14. Waseem M., Kumar S.S., Serajuddin M., Mahdi F. et al. Association of MTHFR (C677T) Gene Polymorphism with Breast Cancer in North India. Biomarkers in Cancer. 2016. Vol. 8. P. 111-117.

15. Bandazhevskyi Yu.I., Dubova N.F. The Role of Genome of Folate Metabolism in the Occurrence of Hyperhomocysteinemia in Children from the Areas Affected by the Chornobyl Nuclear Power Plant Accident. Scientific and Practical Collection «Chornobyl: Ecology and Health». Ivankiv: PI Coordination and Analytical Center «Ecology and health»; Dnipro: Serednyak T.K. ; 2017 ; 6 : 27-35.

16. Zhang X., Liu T., Li Y. and Li S. Association between MTHFR 677C/T and 1298A/C Gene Polymorphisms and Breast Cancer Risk. Genet. Mol. Res. 2015 ; 14 (4) : 16425-16430.

17. Grechanina E.Ya., Malaton R., Grechanina Yu.B. et al. Nasledstvennye narusheniya obmena serosoderzhashchikh aminokislot [Hereditary Metabolic Disorders of Sulfur-Containing Amino Acids]. Rossiyskiy vestnik perinatalogii i pediatrii. 2008 ; 6 : 57-65 (in Russian).

18. Vayner A.S., Kudryavtseva E.A., Zhechev D.A. et al. Issledovaniye assotsiatsii polimorfizma genovfolatnogo obmena s riskom vrozhdennykh anomaliy razvitiya [Study of the Association of Folate Metabolism Gene Polymorphism with the Risk of Congenital Malformations]. Mat I ditya v Kuzbasse. 2011 ; 3 (46) :10-16 (in Russian).

19. Bandazhevskyi Yu.l. and Dubova N.F. Pozhezhi lisu v Chornobylskii zoni vidchuzhennia ta zdorovia ditei [Forest Fires in the Chornobyl Exclusion Zone and Children's Health]. Ivankiv, Ukraine : Coordination Analytical Center «Ecology and Health»; Dnipro, Ukraine : Serednyak T.K. ; 2020 : 42 p. (in Ukrainian).

Надійшло до редакції 14.11.2020 удк 612.354:616.36-055:

https://doi.org/10.32402/

616-001.28 dovkil2021.01.035

ЗАКОНОМІРНОСТІ ФОРМУВАННЯ ЗАХВОРЮВАНЬ ПЕЧІНКИ У ПОСТРАЖДАЛИХ ВНАСЛІДОК АВАРІЇ НА ЧОРНОБИЛЬСЬКІЙ АЕС

Чумак А.А., Саркісова Е.О., Альохіна С.М., Медведовська Н.В., Овсяннікова Л.М., Малишевська Є.М.

\section{PATTERNS OF LIVER DISEASE FORMATION IN VICTIMS OF THE CHORNOBYL NUCLEAR POWER PLANT ACCIDENT}

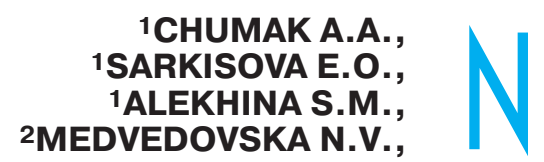

on-alcoholic fatty liver disease (NAFLD) is a problem not only of modern hepatology, but 1,20VSIANNIKOVA M 1,2MALYSHEVSKA Y.M

1State Institution «National Research Center for Radiation

Medicine of the NAMS of Ukraine»

2Scientific Coordination

Department of the National Academy of Medical Sciences , of Ukraine also has a global importance for the state of human health, which is both due to the broad reach and the consequences of the progression of this pathology - the development of the liver cirrhosis, hepatocellular carcinoma, liver-cell deficiency [1].

\section{ЗАКОНОМІРНОСТІ ФОРМУВАННЯ ЗАХВОРЮВАНЬ}

ПЕЧІНКИ У ПОСТРАЖДАЛИХ ВНАСЛІДОК АВАРІЇ

НА ЧОРНОБИЛЬСЬКІЙ АЕС

1 Чумак А.А., 1Саркісова Е.О., 1Альохіна С.М.,

2Медведовська Н.В., 1,2Овсяннікова Л.М.,

1,2Малишевська Є.M.

1 ДУ «Національний науковий центр радіаційної медицини НАМН України», м. Київ

2Науково-координаційне управління НАМН України, м. Київ

Метою дослідження стало визначення механізмів формування та прогредієнтності хронічних дифузних захворювань печінки у постраждалих внаслідок аварії на ЧАЕС з розробкою діагностичних критеріїв фіброзних змін з цією патологією.

Матеріалами дослідження були результати обстеження та лікування в умовах клініки Ду «ННЦРМ НАМН України» постраждалих внаслідок Чорнобильської катастрофи, 57 з яких, за критеріями включення та виключення, було віднесено до основної групи.

Методи дослідження: загальноклінічне обстеження, інструментальні дослідження (ультразвукова діагностика органів черевної порожнини), біохімічні, медико-статистичні, інформаційно-аналітичні.

Результати дослідження. Доведено, що у постраждалих внаслідок Чорнобильської катастрофи основною патологією печінки є неалкогольна жирова хвороба печінки (НАЖХП), на тлі якої розвивається виражене порушення жирового обміну, достовірне зниження холестерину, бета-ліпопротеїдів, що можна вважати маркером розвитку цирозу в УЛНА, хворих на НАЖХП; наведено чинники прогресування цирозу з маніфестацією захворювання на стадії декомпенсації.

Ключові слова: постраждалі внаслідок Чорнобильської катастрофи, хронічні дифузні захворювання печінкИ, НАЖХП, НАСГ.

() Чумак А.А., Саркісова Е.О., Альохіна С.М., Медведовська Н.В., Овсяннікова Л.М., Малишевська Є.М. СТАТТЯ, 2021. 
Research of the pathogenesis, etiological factors, and the clinical picture demonstrate that NAFLD is a component of MS, and some scientists consider this pathology to be a factor in the development of MS. Pathological changes in the liver with NASH are associated with activation of lipid peroxidation (LPO) along with inhibition of the functional activity of the antioxidant defense system. This process, together with the formation of active radicals, leads to mitochondria and cell membrane damage [6]

LPO processes are initiators in the progression of systemic inflammation and forced atherogenesis, even in the absence of obesity. They have immunogenic properties and potentiate processes of oxidative modification of biomolecules, both in the hepatocytes themselves and in the peripheral bloodstream, while activating mononuclear phagocytes that release anti-inflammatory mediators. The activity of the main antioxidant protection enzymes (superoxide dismutase and catalase) increases during the NAFLD progression; however, their depletion occurs during the transition to the fibrosis and cirrhosis stage [7].

Thus, oxidative stress against the backdrop of lipid encumbrance on the body contributes to the manifestations of the effects of cytotoxicity and inhibition of fatty acid oxidation, which activates the processes of LPO. The disorder in the composition of lipid membranes is significant for the development of IR and the manifestation of lipotoxicity effects due to the formation of fatty bodies in insulin-dependent tissues, that activate antiinflammatory and pro-atherogenic mechanisms, thus producing a systemic inflammatory response that aggravates NAFLD with comorbid conditions, involving different organs and the body as an entire system.

In recent decades, pathogenetic mechanisms have been identified, confirming that
NAFLD ought to be considered as a multisystem disease. Comorbid pathology occurs in $80-95 \%$ of patients over the age of 60 years old. There is no exception as to those who experienced the effects of the Chornobyl accident factors, which became a negative cause in changes to the state of health of the population over large territories of three countries - Ukraine, Belarus and the Russian Federation. Certain studies based on the analysis of official medical statistics and registers reported on the deterioration in health, increase in number of non-neoplastic diseases, development of respiratory organs, cardiovascular, digestive and endocrine system diseases among the Chornobyl accident clean-up personnel and in population of radiologically contaminated areas [9]

A characteristic feature of the state of health of the Chornobyl accident clean-up personnel is the presence of several chronic diseases, ranging from 5 to 13 diseases recorded concurrently. Among the evacuated population, there is also a noted increase in risks and a reliable increase in the number of nonneoplastic diseases with an increase in the level of doses of external radiation. According to Mironenko T.V. et al (2010), when assessing the somatic status of the Chornobyl accident clean-up personnel who received a dose radiation of up to 0.3 Gy and who suffer from dyscirculatory encephalopathy, there were 4-5 somatic diseases per person examined. Among them, cardiovascular system $(65,5-80,0 \%)$ and gastrointestinal system $(65,0$ $75,0 \%)$ diseases, musculoskeletal system $(30,0-50,0$ $\%)$ and thyroid gland $(40,0$ $55,0 \%$ pathologies were observed most often $[8,17]$.

There are reports on a possible dependence between the severity of somatic and mental disorders and the level of dose burden in persons affected by ionizing radiation as a result of the Chornobyl accident [8].

The results of the clinical data hemostasis disorders, hyperuricemia, microalbuminuria [5] . 
PATTERNS OF LIVER DISEASE FORMATION IN VICTIMS OF THE CHORNOBYL NUCLEAR POWER PLANT ACCIDENT

1 Chumak A.A., 1Sarkisova E.O., 1AlekhinaS.M., 2 Medvedovska N.V., 1,2Ovsiannikova L.M., 1,2Malyshevska Y.M 1 State Institution «National Research Center for Radiation Medicine of the NAMS

of Ukraine», Kyiv, Ukraine

${ }^{2}$ Scientific Coordination Department of the National Academy of Medical Sciences of Ukraine, Kyiv, Ukraine

The aim of the study is to determine the mechanisms for the formation and progressivity of chronic diffuse liver diseases in victims of the Chornobyl Nuclear Power Plant accident with the development of a diagnosis criteria for fibrous changes in this pathology.

The materials were the results of examination and treatment in the clinic of the State Institution "NRCRM of the NAMS of Ukraine» of victims of the Chornobyl Nuclear Power Plant accident, 57 of which, according to the criteria for switching on and off, were assigned to the main group. The research methods were: general clinical examination, instrumental studies (ultrasound diagnostics of abdominal organs), biochemical, medical statistics, analytical.

According to the results of the study, it was proved that in the victims of the Chornobyl Nuclear Power Plant accident, the main liver pathology was non-alcoholic fatty liver disease. It has been shown that in patients affected by the Chornobyl disaster, NAFLD develops a pronounced violation of fat metabolism with a reliable decrease in cholesterol and betalipoproteins in cirrhosis - a sign of a long-term course of the disease, accompanied not only by the development of fibrosis, but also by a fatty rebirth of liver tissue with low cholesterol and beta-lipoproteins; this can be considered a marker of cirrhosis in the Chornobyl accident clean-up personnel with NAFLD.

\section{Keywords: victims of the Chornobyl Nuclear Power Plant accident, chronic diffuse liver diseases, NAFLD, NASH.}

analysis of the changes in the main systems of the organisms of the Chornobyl accident clean-up personnel indicate that they are more often polysyndromic in nature (hematoimune, cardiovascular, gastroenteral, bronchopulmonary and polyneuropathic syndromes with the development of metabolic syndromes of oxidative destruction, insulin and leptin resistance, carbohydrate and lipid metabolism disorders, hormonal changes).

In the period after the accident, there is a persistent tendency towards an increased prevalence of comorbid diseases, the pathogenetic basis of which is considered to be a systemic inflammatory reaction with the alteration of microcirculatory vessels against the background of oxidative stress, endothelial dysfunction, immunopathological and destructive-dystrophic changes [16].

Thus, the above is a convincing evidence as to the relevance of determining the mechanisms for the formation of chronic diffuse liver diseases that lead to irreversible changes in the state of health of the Chornobyl Nuclear Power Plant accident victims.
The aim of the study is to determine the mechanisms for the formation and progressivity of chronic diffuse liver diseases in victims of the Chornobyl Nuclear Power Plant accident with the development of a diagnosis criteria for fibrous changes in this pathology.

The subject of the study was the hepatobiliary system in patients examined and treated at the SI «NRCRM of the NAMS of Ukraine» clinic.

Research materials and methods. The contingent of respondents was represented by the Chornobyl accident

clean-up personnel, evacuees from the $30-\mathrm{km}$ zone and the city of Pripyat and inhabitants of the territories with the strengthened radiation control (territory with the contamination density with isotopes ${ }^{137} \mathrm{Cs}$ from $185 \mathrm{kBk} / \mathrm{m}^{2}$ to $555 \mathrm{kBk} /$ $\mathrm{m}^{2}$ and/or $90 \mathrm{Sr}$ from $5.55 \mathrm{kBk}$ / $\mathrm{m}^{2}$ to $111 \mathrm{kBk} / \mathrm{m}^{2}$ ).

The main group included 57 people with NASH and $\mathrm{SH}$ and who were affected by the Chornobyl accident. Respondents were represented by males between the ages of 31 and 70 (table 1). The average age of patients was $(57,3 \pm 1,1)$

Table 1

Distribution of patients affected by the Chornobyl Nuclear Power Plant accident, NAFLD stage and complications

\begin{tabular}{|c|c|c|c|}
\hline \multirow[b]{2}{*}{ Nosology form } & \multirow[b]{2}{*}{ ICD cipher } & \multicolumn{2}{|c|}{ Number of patients } \\
\hline & & $\begin{array}{l}\text { absolute } \\
\text { quantity }\end{array}$ & $\%$ \\
\hline STEATOHEPATOSIS & K76 & 33 & 57,9 \\
\hline $\begin{array}{l}\text { NON-ALCOHOLIC STEATOHEPATITIS } \\
\text { OF MINIMAL ACTIVITY }\end{array}$ & K73.9 & 13 & 22,8 \\
\hline STEATOSIS HEPATOSPLENOMEGALY & K76 R16.2 & 4 & 7 \\
\hline $\begin{array}{l}\text { NON-ALCOHOLIC STEATOHEPATITIS } \\
\text { OF MINIMAL ACTIVITY } \\
\text { HEPATOSPLENOMEGALY }\end{array}$ & K73.9 R16.2 & 6 & 10,5 \\
\hline $\begin{array}{l}\text { NON-ALCOHOLIC STEATOHEPATITIS } \\
\text { OF MINIMAL ACTIVITY VARICOSE } \\
\text { VEINS OF THE ESOPHAGUS }\end{array}$ & K73.9 R16.2 & 1 & 1,8 \\
\hline
\end{tabular}


years old with the predominance of those aged from 51 to 60 years old $(43,9 \%)$.

Research methods - general clinical examination, instrumental studies (ultrasound diagnostics of abdominal organs), biochemical, medical statistics, analytical.

Ultrasound diagnostics of the abdominal organs was carried out on the following devices: Shiwadzy 410B (Japan), Aloka2000 (Japan), Aloka-650 (Japan) in accordance with the standard procedure.

The diagnosis of NAFLD was established in patients with signs of metabolic syndrome during an ultrasound examination of the liver: distal echo signal attenuation («bright liver»); increased liver echogenicity compared to kidneys; fuzzy vascular pattern.

The condition of the patients' liver was examined according to the following indicators and conventional laboratory methods: total protein level - by the biuretic method, protein fractions - by electrophoresis on cellulose acetate pellice, albumin - by color reaction with bromo-cresol green, bilirubin - by colorimetric method (diazomethode) by Jendrashik, aspartate aminotransferase (AST) and alanine aminotransferase (ALT) activity - by colorimetric kinetic method (Thermo Scientific kits, Finland), gamma-glutamyl transpeptidases - by colorimetric method («GT liquicolor» set, Human, Germany), alkaline phosphatase - by the kinetic method on

\section{Frequency of detection of signs of liver structure change based on results of ultrasound of abdominal organs of NAFLD patients affected by the Chornobyl Nuclear Power Plant accident}

\begin{tabular}{|l|c|c|}
\hline \multirow{2}{*}{\multicolumn{1}{|c|}{ Indicator }} & \multicolumn{2}{c|}{ Number of cases } \\
\cline { 2 - 3 } & absolute quantity & $\%$ \\
\hline Liver Size Increase & 48 & 84,2 \\
\hline Increased liver echogenicity & 50 & 87,7 \\
\hline Coarse-grained liver pattern & 21 & 36,8 \\
\hline Depletion of vascular pattern & 18 & 31,6 \\
\hline Ultrasonic signal attenuation & 5 & 8,8 \\
\hline Heterogeneous structure & 4 & 7,0 \\
\hline Portal System Wall Compaction & 2 & 3,5 \\
\hline Bright vascular pattern & 2 & 3,5 \\
\hline
\end{tabular}

inal ultrasound of NAFLD patients, liver enlargement was determined in $48(84,2 \%)$ cases (Table 2).

In the clinical picture of NAFLD, for victims of the Chornobyl accident prevailed symptoms of the concomitant pathology of the digestive system - the stomach, duodenum, bile tract, with pain $(78,3-$ $81,6 \%)$ and dyspeptic $(64,5$ $67,8 \%)$ syndromes. In NASH, astheno-vegetative syndrome $(74,7 \%)$, increased blood pressure $(74,7 \%)$, inflammatory processes $(50 \%)$ were determined more often than in the comparison group (CG).

Concomitant cerebrovascular and cardiovascular pathology in NAFLD patients affected by the Chornobyl accident was determined concurrently in most cases $(77,2 \%)$. The most frequent among cerebrovascular diseases $(35,5 \%)$ cases was dyscirculatory encephalopathy, as well as chronic cerebral circulation disorder (CPMK) $(29,8 \%)$ cases. $7 \%$ of NAFLD patients suffered with the acute cerebral circulation disorder.

Concomitant cardiovascular pathology in the studied group of patients with NAFLD was represented by hypertension (17\%). In $3,4 \%$ of patients with NAFLD, rhythm disorders were established - one case of paroxysmal form of atrial fibrillation and one case of extrasystolic arrhythmia. Coronary heart disease was detected in $31,6 \%$ of patients. Stage I heart failure had $36,8 \%$ of patients with NAFLD, stage II A - 5,2\%. The diagnosis of aortic atherosclerosis was established in $10,5 \%$ of patients.

IA difference was found in the dynamics of inflammatory process indicators in the liver in NAFLD in patients of the main group and the comparison group (CG), the marker of which is the activity of transaminases. AST activity significantly increased in patients with NASH compared to those with $\mathrm{SH}$ as in victims of the Chornobyl accident $(52,81 \pm 3,77) \mathrm{U} / \mathrm{L}$, and in CG $(47,51 \pm 2,78) \quad U / L$. ALT activity in NAFLD patients 
ЗАКОНОМЕРНОСТИ ФОРМИРОВАНИЯ ЗАБОЛЕВАНИЙ ПЕЧЕНИ У ПОСТРАДАВШИХ ВСЛЕДСТВИЕ АВАРИИ

НА ЧЕРНОБЫЛЬСКОЙ АЭС

1 Чумак А.А., 1Саркисова Э.А., 1 Алёхина С.М. 2 Медведовская Н.В., 1,2Овсянникова Л.М.,

1,2Малышевская E.M.

1 ГУ «Национальный научный центр радиационной медицины НАМН Украины»

2Научно-координационное управление НАМН Украины

\section{Целью исследования стало определение механизмов формирования и прогредиент- ности хронических диффузных заболеваний печени у пострадавших вследствие аварии на ЧАЭС с разработкой диагностических критериев фиброзных изменений при этой патологии. \\ Материалами исследования были результаты обследования и лечения в усло- виях клиники ГУ «ННЦРМ НАМН Украины» пострадавших вследствие Чернобыльской катастрофы, 57 из которых, по критериям}

включения и исключения, были отнесены к основной группе.

Методы исследования: общеклиническое обследование, инструментальные исследования (ультразвуковая диагностика органов брюшной полости), биохимические, медико-статистические, информационно-аналитические.

Результаты исследования доказали, что у пострадавших вследствие Чернобыльской катастрофы основной патологией печени была неалкогольная жировая болезнь печени (НАЖБП), на фоне которой развивалось выраженное нарушение жирового обмена, достоверное снижение холестерина, беталипопротеидов, что можно считать маркером развития цирроза печени у участников ликвидации последствий аварии на ЧАЭС, больных НАЖБП. Приведены факторы прогрессирования цирроза с манифестацией заболевания на стадии декомпенсации.

Ключевые слова: пострадавшие вследствие Чернобыльской катастрофы, хронические диффузные заболевания печени, НАЖБП, НАСГ. increased with NASH both in the main group $(64,24 \pm 2,93) \mathrm{U} / \mathrm{L}$ and in CG $(71,08 \pm 4,60) \mathrm{U} / \mathrm{L}$, with a decrease in liver cirrhosis in patients of the main group $(58,84 \pm 23,35) \mathrm{U} / \mathrm{L}$ and in CG $(48,40 \pm 16,57) \mathrm{U} / \mathrm{L}$.

In SH patients, AST activity in Chornobyl victims was significantly higher than in CG $(27,68 \pm$ $0,93) U / L$ and $(23,34 \pm 11,15)$ $\mathrm{U} / \mathrm{L}$, and in liver cirrhosis, AST activity was significantly higher in CG patients - $(122,86 \pm 42,53)$ $\mathrm{U} / \mathrm{L}$ and $(86,76 \pm 29,68) \mathrm{U} / \mathrm{L}$.

For the Chornobyl disaster clean-up personnel suffering from NAFLD with the development of liver fibrosis, cytolytic syndrome activity was significantly increased with a progressive increase in transaminase activity - AST - (31,25 \pm $0,62) U / L,(57,90 \pm 11,64) U / L$, $(159,4 \pm 35,21) \mathrm{U} / \mathrm{L}, \mathrm{ALT}-$ $(38,65 \pm 1,32) U / L, \quad(68,5 \pm$ $4,20) U / L, \quad(117,25 \pm 25,73)$ $\mathrm{U} / \mathrm{L}$, and the Ritis coefficient AST/ALT - (0,91 $\pm 0,02),(1,03$ $\pm 0,08), \quad(1,61 \pm 0,18)$. Cholesterol levels were significantly reduce $-(5,51 \pm 0,17)$ $\mu \mathrm{mol} / \mathrm{L}, \quad(5,34 \pm 0,33) \mathrm{\mu mol} / \mathrm{L}$. The same changes, namely a significant decrease in betalipoproteins level in blood were observed in these groups of patients $-(48,69 \pm 3,08) \mathrm{U} / \mathrm{L}$, $(45,42 \pm 3,25) \mathrm{U} / \mathrm{L}$.

Cholestasis syndromes were formed with a reliable increase in the activity of the enzyme gamma-glutamyl transpeptidase (GGTP) - $(39,15 \pm 3,25)$ $\mathrm{U} / \mathrm{I}, \quad(82,41 \pm 12,38) \quad \mathrm{U} / \mathrm{I}$, $(139,92 \pm 31,29) \mathrm{U} / \mathrm{I}$, hepatic cell failure with a progressive increase in bilirubin $(14,19 \pm$ 0,53) $\mu \mathrm{mol} / \mathrm{L}, \quad(17,07 \pm 1,12)$ $\mu \mathrm{mol} / \mathrm{L},(22,64 \pm 3,16) \mu \mathrm{mol} / \mathrm{L}$, as well as impaired protein synthesizing liver function with reduced albumin $(36,3 \pm 1,86)$ $\mathrm{g} / \mathrm{l}$, and an increase in the acute phase protein alpha 2macroglobulin $(2,76 \pm 0,45)$ $\mathrm{g} / \mathrm{l}$, which activates astrocytes and stimulates fibrogenesis, the development of dysproteinemia and mesenchymalinflammatory changes with a gradual increase in the thymol sample with reliability at the stage of pronounced fibrotic changes $(2,39 \pm 0,53)$ units, $(2,70 \pm 0,28)$ units, $(4,49 \pm$ 0,77 ) units.

Activation of lipoperoxidation processes with accumulation of secondary TBA active products observed in most patients at risk of developing severe cardiovascular complications (76\% of those examined).
Changes in the hepatobiliary system for the Chornobyl disaster clean-up personnel of those who died as a result of liver cirrhosis were characterized by the development of atrophy and fatty dystrophy of hepatocytes, lymphoid-lymphocytic infiltration, pronounced and systemic development of fibrosis, often with massive growth of fibrotic tissue, not only in the liver.

\section{Conclusions}

1. It was established that the main liver pathology for victims of the Chornobyl accident at ChNPP is non-alcoholic fatty liver disease. The main trigger in the launch of the mechanism for the development of pathological processes in the liver is oxidative stress with a breakdown of the antioxidative protection of cells, accompanied by the development of the state of peroxidation, while disorders of energy metabolism and general cell metabolism occur.

2 . It has been shown that in patients affected by the Chernobyl accident, NAFLD develops a pronounced violation of fat metabolism with a reliable decrease in cholesterol and beta-lipoproteins in cirrhosis - a sign of a long-term 
course of the disease, accompanied not only by the development of fibrosis, but also by a fatty rebirth of liver tissue with low cholesterol and betalipoproteins; this can be considered a marker of cirrhosis in the Chornobyl accident cleanup personnel with NAFLD.

3. It was established that for the Chornobyl accident cleanup personnel with NAFLD and the development of liver fibrosis, cytolytic syndrome activity was significantly increased with a progressive increase in transaminase activity - AST and ALT, cholestasis, hepatic cell insufficiency were formed with a progressive increase in bilirubin, as well as impaired protein synthetic liver function with a decrease in albumin and an increase in the acute phase protein alpha 2-macroglobulin, which activates astrocytes and stimulates fibrogenesis with the development of dysproteinemia and mesenchymal-inflammatory changes with a gradual increase in thymolic sample at the stage of pronounced fibrous changes.

4. Factors of the liver cirrhosis progression with disease manifestation at decompensation stage were: long steadily progressing processes of inflammation, asymptomatic or lowsymptomatic course with minimal activity and/or absence of cytolytic syndrome, improper dynamic observation and uncontrolled course of the disease, significant amount of comorbidity of other organs and systems.

\section{ЛITEPATYPA}

1. Chalasani N., Younossi Z., Lavine J.E., Diehl E.M. et al. The diagnosis and management of non alcoholic fatty liver disease: Practice Guideline by the American Association for the Study of Liver Diseases, American College of Gastroenterology, and the American Gastroenterological Association. Hepatology. 2012. Vol. 55 (6). P. 2005-2023.

2. Пирогова О.Я. та ін. Епідеміологія непухлинних захворювань: Евакуйовані. Медичні наслідки
Чорнобильської катастрофи: монографія / за ред.

А.М. Сердюка, В.Г. Бебешка, Д.А. Базики. Тернопіль : ТДМУ, 2011. С. 379-410.

3. Бабак О.Я. Причины и метаболические последствия неалкогольной жировой болезни печени. Сучасна гастроентерологія. 2010. № 4 (54). С. 8-16.

4. Діденко В.І., Кленіна І.А., Татарчук О.М., Петішко О.П.

Зв'язок імунологічних та біохімічних показників у хворих на хронічні дифузні захворювання печінки залежно від етіологічних факторів розвитку стеатозу і фіброзу печінки. Гастроентерологія. 2019. T. 53 (2). C. 50-57.

5. Treeprasertsuk S.F., Lopez-Jimenez, Lindor K.D. Nonalcoholic fatty liver disease and the coronary artery disease. Digestive Diseases and Sciences. 2011. Vol. 56 (1). P. 35-45.

6. Пруднікова І.В.

Активність ліпопероксидації та стан антиоксидантної системи у хворих на неалкогольний стеатогепатит у поєднанні з ожирінням. Сучасна гастроентерологія. 2009. № 6 (50). C. 38-41.

7. Ovsyannikova L., Chumak A., Nosach O. et. al. Antioxidant system, oxidative modification of proteins and lipids. Health effects of the Chornobyl Accident a Quarter of Century Aftermath /A. Serdiuk, V. Bebeshko, D. Bazyka, S. Yamashita (eds.). Kyiv : DIA, 2011. Chapter 14. P. 419-432.

\section{8. Мироненко Т.В.,}

Пеннер В.А., Пицул Н.Л., Лавренко О.В., Казарцева М.Н. Дисциркуляторная энцефалопатия и её сочетание с другими заболеваниями нервной системы у участников ликвидации последствий аварии на ЧАЭС (диагностические и терапевтические подходы). Междунар. неврол. журн. 2010. № 4 (34). C. 30-40.

9. Біохімічні та біофізичні методи оцінки порушень окислювального гомеостазу в осіб, що зазнали радіацій- ного впливу внаслідок аварії на ЧАЕС : Метод. рекомендації / Наук. центр радіац. медицини АМН України ; уклад. Л.М. Овсяннікова та ін. К., 1999. 18 с.

10. Волчегорский И.А., Налимов Ф.Г., Яровинский Б.Г., Лифшиц Р.И. Сопоставление различных подходов к определению продуктов ПОЛ в гептан-изопропанольных экстрактах крови. Вопросы мед. химии. 1989. № 1. С. 127-131.

11. Гаврилов В.П., Гаврилова А.Р., Майорова И.Г. Методика определения малонового диальдегида в сыворотке крови. Вопросы мед. химии. 1987. № 1.

С. 118-122.

12. Levine R.L., Garland D., Oliver C.N. et. al.

Determination of carbonyl content in oxidatively modified proteins. Meth. Enzymol. 1990. Vol. 186. P. 464-478.

13. Дубинина Е.E.,

Ковругина С.В., Морозова М.Г. и др. Окислительная модификация белков плазмы крови больных психическими расстройствами (депрессия, деперсонализация). Вопр. мед. химии. 2000. Т. 46 (4). С. 398-409.

14. Misra H.P., Fridovich I. The generation of superoxide radical during the autoxidation of hemoglobin. J. Biol. Chem. 1972. Vol. 247 (21).

C. $6960-6962$.

15. Королюк М.А., Иванова Л.И., Майорова И.Г., Токарев В.Е. Метод определения активности каталазы. Лаб. дело. 1988. № 1.

С. 16-19.

16. Gastaldelli A., Rozakova M., Hujlund K. Fatty Liver is associated with insulin resistance, risk of coronary heart disease, and early atherosclerosis in a large European population. Hepatology. 2009. Vol. 49. C. 1537-1544.

17. Singh R., Wang J., Schattenberg J.M. et al. Chronic oxidative stress sensitizes hepatocytes to death from 4-hydroxynonenal by JNK/c-Jun overactivation. Am. J. Physiol. Gastrointest. Liver 
Physiol. 2009. Vol. 29 (5).

P. 907-917.

\section{REFERENCES}

1. Chalasani N., Younossi Z., Lavine J.E., Diehl E.M. et al.

The Diagnosis and

Management of Non Alcoholic

Fatty Liver Disease: Practice

Guideline by the American

Association for the Study of

Liver Diseases, American

College of Gastroenterology,

and the American

Gastroenterological

Association. Hepatology. 2012

; Vol. 55 (6) : 2005-2023.

2. Pyrohova O.Ya. et al.

Epidemiolohiia nepukhlynnykh

zakhvoriuvan: Evakuiovani

[Epidemiology of Non-

Neoplastic Diseases: The

Evacuees]. In : A.M. Serdiuk,

V.H. Bebeshko, D.A. Bazyka

(eds.). Medychni naslidky

Chornobylskoi katastrofy:

monohrafiia [Medical

Consequences of the

Chornobyl Disaster:

Monograph]. Ternopil, Ukraine ; 2011 : 379-410 (in Ukrainian).

3. Babak O.Ya. Prichiny i metabolicheskiye posledstviya nealkogolnoy zhirovoy bolezni pecheni [Causes and

Metabolic Consequences of

Non-Alcoholic Fatty Liver

Disease]. Suchasna hastroen-

terolohiia. 2010 ; 4 (54) : 8-16

(in Russian).

4. Didenko V.I., Klenina I.A., Tatarchuk O.M. and

Petishko O.P. Zviazok imunolo-

hichnykh ta biokhimichnykh

pokaznykiv u khvorykh na

khronichni dyfuzni zakhvoriuvannia pechinky zalezhno vid etiolohichnykh faktoriv rozvytku steatozu i fibrozu pechinky

[Relationship Between

Immunological and

Biochemical Parameters in

Patients with Chronic Diffuse

Liver Disease Depending on

the Etiological Factors of

Steatosis and Liver Fibrosis].

Hastroenterolohiia. 2019 ;

53 (2) : 50-57 (in Ukrainian).

5. Treeprasertsuk S.F., Lopez-Jimenez and Lindor K.D. Nonalcoholic Fatty Liver Disease and the Coronary Artery Disease. Digestive Diseases and Sciences. 2011; Vol. 56 (1) : 35-45.
6. Prudnikova I.V. Aktyvnist lipoperoksydatsii ta stan antyoksydantnoi systemy u vorykh na nealkoholnyi steatohepatyt u poiednanni iz ozhyrinniam [The Activity of Lipoperoxidation and Antioxidant System in the Patients with Non-Alcoholic Steatohepatitis in Connection with Obesity]. Suchasna hastroenterolohiia. 2009 ; 6 (50) : 38-41 (in Ukrainian).

7. Ovsyannikova L.,

Chumak A., Nosach O. et. al. Antioxidant System, Oxidative Modification of Proteins and Lipids. Health Effects of the Chornobyl Accident - a Quarter of Century Aftermath /

A. Serdiuk, V. Bebeshko, D. Bazyka, S. Yamashita (eds.). Kyiv : DIA, 2011 ; Chapter 14 : 419-432.

8. Mironenko T.V., Penner V.A., Pitsul N.L., Lavrenko O.V. and Kazartseva M.N.

Distsirkulyatornaya entsefalopatiya I ee sochetanie s drugimi zabolevaniyami nervnoy sistemy u uchastnikov likvidatsii posledstviy avarii na ChAES (diagnosticheskie I terapevticheskie podkhody). Mezhdunarodnyy nevrologicheskiy zhurnal. 2010 ; 4 (34) : 30-40 (in Russian).

9. Ovsiannikova L.M. et al. Biokhimichni ta biofizychni metody otsinky porushen okysliuvalnoho homeostazu v osib, shcho zaznaly radiatsiinoho vplyvu vnaslidok avarii na ChAES : Metodychni rekomendatsii [Biochemical and Biophysical Methods for the Assessment of Oxidative Homeostasis Disorders in Persons Exposed to Radiation as a Result of the Chornobyl Accident: Guidelines].

Scientific Centre of Radiation Medicine of the Academy of Medical Science of Ukraine. Kyiv ; 1999 :18 p. (in Ukrainian).

10. Volchegorskiy I.A. NalimovF.G., Yarovinskiy B.G. and Lifshits R.I. Sopostavleniye razlichnykh podkhodov k opredeleniyu produktov POL v geptan-izopropanolnykh ekstraktakh krovi [Comparison of Different Approaches to the Determination of OLD Products in Heptane-Isopropanol Blood Extracts]. Voprosy meditsinskoy khimii. 1989 ; 1 : 127-131 (in Russian).

11. Gavrilov V.P., Gavrilova A.R. and Mayorova I.G. Metodika opredeleniya malonovogo dialdegida $v$ syvorotke krovi [Method for Determination of Malondialdehyde in Blood Serum]. Voprosy meditsinskoy khimii. 1987 ; 1 : 118-122 (in Russian).

12. Levine R.L., Garland D., Oliver C.N. et. al.

Determination of Carbonyl Content in Oxidatively Modified Proteins. Meth. Enzymol. 1990 ; $186:$ :464-478.

13. Dubinina E.E., Kovrugina S.V., Morozova M.G. et al. Okislitelnaya modifikatsiya belkov plazmy krovi bolnykh psikhicheskimi rasstroystvami (depressiy, depersonalizatsiya) [Oxidative Modification of Blood Plasma Proteins in the Patients with Mental Disorders (Depression,

Depersonalization)]. Voprosy meditsinskoy khimii. $2000 ; 46$ (4) : 398-409 (in Russian).

14. Misra H.P. and

Fridovich I. The Generation of Superoxide Radical During the Autoxidation of Hemoglobin.

J. Biol. Chem. 1972 ; 247 (21) : 6960-6962.

15. Korolyuk M.A., Ivanova L.I., Mayorova I.G. and Tokarev V.E. Metod opredeleniya aktivnosti katalazy [Method for the Determination of Catalase Activity]. Laboratornoe delo. 1988 ; 1 : 16-19 (in Russian).

16. Gastaldelli A., Rozakova M., Hujlund K. Fatty Liver is Associated with Insulin Resistance, Risk of Coronary Heart Disease, and Early Atherosclerosis in a Large European Population. Hepatology. 2009 ; 49 : 1537-1544.

17. Singh R., Wang J., Schattenberg J.M. et al. Chronic Oxidative Stress Sensitizes Hepatocytes to Death from 4-hydroxynonenal by JNK/c-Jun Overactivation. Am. J. Physiol. Gastrointest. Liver Physiol. 2009 ; 29 (5) : 907-917.

Надійшло до редакції 05.12.2020 